\title{
Angka kejadian lesi yang diduga sebagai Stomatitis Aftosa Rekuren pada mahasiwa Program Studi Kedokteran Gigi Fakultas Kedokteran Universitas Sam Ratulangi
}

\author{
${ }^{1}$ P. L. Suling, ${ }^{1}$ Ellen Tumewu, ${ }^{1}$ Joenda S. Soewantoro, ${ }^{2}$ Anom Y. Darmanta \\ ${ }^{1}$ Program Studi Kedokteran Gigi \\ ${ }^{2}$ Mahasiswa Program Studi Kedokteran Gigi \\ Fakultas Kedokteran Universitas Sam Ratulangi
}

\begin{abstract}
ABSTRAK
Stomatitis Aftosa Rekuren (SAR) yang lebih dikenal orang awam dengan sebutan sariawan merupakan penyakit mukosa mulut yang paling sering terjadi. Prevalensi rata-rata pada populasi dunia yaitu 20\%. Prevalensi tertinggi terjadi pada pelajar di Amerika Utara, dimana sebagian besar terjadi saat ujian. Kelompok sosial ekonomi menengah ke atas lebih sering mengalami SAR.

Penelitian ini merupakan penelitian cross-sectional study. Penelitian dilakukan dengan maksud untuk mengetahui angka kejadian lesi yang diduga sebagai SAR berdasarkan faktor predisposisi pada mahasiswa Program Studi Kedokteran Gigi Fakultas Kedokteran Universitas Sam Ratulangi yang pernah mengalami lesi yang diduga sebagai SAR. Faktor predisposisi yang diteliti yaitu, trauma, ketidakseimbangan hormonal, alergi, stres dan genetik.

Dari penelitian ini diperoleh hasil sebesar $68,2 \%$ responden pernah mengalami lesi yang diduga sebagai SAR dan faktor predisposisi yang paling banyak memicunya yaitu trauma sedangkan yang paling sedikit yaitu alergi. Pada masa hidupnya, seseorang mengalami SAR bukan hanya disebabkan oleh satu faktor saja melainkan dapat juga disebabkan oleh beberapa faktor predisposisi SAR.
\end{abstract}

Kata kunci : Stomatitis Aftosa Rekuren, SAR, faktor predisposisi.

\section{ABSTRACT}

Recurrent Aphtous Stomatitis (RAS) better known as sariawan, is the most common oral disease. The average prevalence in world population is $20 \%$. The highest prevalence is among North American students, where occurance of disease is mostly during examination time. Middle-upper socio-economic class people suffer RAS more often.

This research is a cross-sectional study. This research is conducted with the intention to find out the incidence of RAS based on the predisposing factors in the students of Program Studi Kedokteran Gigi Fakultas Kedokteran Universitas Sam Ratulangi who have history of RAS. The predisposing factors that were examined are trauma, hormonal imbalances, allergies, stress dan genetic.

The result of the research shows 68,2\% of respondents have suffered RAS and the predisposing factor that causes RAS the most is trauma, while allergies is the least. In one lifetime, a person may suffer RAS caused by not only one but several predisposing RAS factors.

Key words: Recurrent Aphtous Stomatitis, RAS, predisposing factors.

Korespondensi : Anom Y. Darmanta, Program Studi Kedokteran Gigi, Fakultas Kedokteran Universitas Sam Ratulangi Manado, Indonesia.E-mail : viopurplelet@yahoo.com

\section{PENDAHULUAN}

Stomatitis Aftosa Rekuren atau disingkat SAR yang juga dikenal dengan istilah aphtae, atau canker sores merupakan suatu penyakit mukosa mulut yang paling sering terjadi. Di Indonesia orang awam lebih mengenalnya dengan istilah sariawan. Karakteristik dari penyakit ini yaitu ditandai oleh ulser berulang yang menyakitkan di rongga mulut dan berbentuk bulat atau oval dan dikelilingi inflamasi. Istilah "stomatitis aftosa rekuren" dapat diartikan sebagai ulser berulang yang terbatas pada rongga mulut saja dan dapat muncul tanpa adanya pengaruh dari penyakit sistemik. ${ }^{1}$

Prevalensi SAR pada populasi dunia bervariasi antara 5\% sampai 66\% dengan rata-rata 20\%. Prevalensi tertinggi terjadi pada pelajar di Amerika Utara, sebagian besar saat ujian, dan pada kelompok sosial ekonomi ke atas. Stomatitis Aftosa Rekuren jarang ditemukan di Bedouin Arab. ${ }^{2,3}$

Sebenarnya SAR merupakan penyakit yang relatif ringan karena tidak bersifat 
membahayakan jiwa dan tidak menular, namun bagi sebagian orang ini sangat mengganggu. Orang-orang yang mengalami SAR akan merasa sangat terganggu terutama dalam hal fungsi pengunyahan, penelanan dan berbicara. Masa penyembuhan SAR yang relatif lama, berkisar antara 7 hari bahkan sampai berbulan-bulan dan sifat penyakit ini yang sering kambuh juga membuat pasien menjadi kurang nyaman.

Stomatitis Aftosa Rekuren merupakan penyakit mulut yang penyebabnya belum diketahui secara pasti, namun ada beberapa faktor predisposisi yang diduga menjadi pencetus SAR. Beberapa faktor predisposisi seperti, stres, alergi makanan, genetik, trauma dan ketidakseimbangan hormonal diduga menjadi pencetus timbulnya SAR. ${ }^{3}$

Berdasarkan survei awal, sebagian besar mahasiswa Program Studi Kedokteran Gigi Fakultas Kedokteran Universitas Sam Ratulangi (PSKG FK Unsrat) pernah mengalami lesi yang diduga sebagai SAR dengan berbagai faktor predisposisi yang diduga menjadi pencetus lesi yang diduga sebagai SAR yang mereka alami.

Penelitian ini bertujuan untuk mengetahui angka kejadian lesi yang diduga sebagai SAR berdasarkan faktor predisposisi pada mahasiswa PSKG FK Unsrat.

\section{BAHAN DAN METODE}

Penelitian ini merupakan penelitian deskriptif yang menggunakan desain potong lintang (cross-sectional). Populasi dalam penelitian ini yaitu seluruh mahasiswa program profesi yang terdaftar di PSKG FK Unsrat Manado yang berdasarkan survei awal berjumlah 195 orang. Besar sampel diperoleh dari penghitungan menggunakan rumus Slovin, sehingga diperoleh sampel sebanyak 66 responden, kemudian diambil sampel pada masing-masing angkatan dengan menggunakan proportional sampling, sehingga diperoleh besar sampel masingmasing angkatan yang dapat dilihat pada Tabel 1. Metode pengambilan sampel dilakukan dengan teknik simple random sampling. Pengambilan sampel dilakukan dengan cara pengundian, dimana seluruh mahasiswa profesi PSKG FK Unsrat diinventaris berdasarkan angkatan. Setiap mahasiswa yang tercantum dalam daftar inventaris memiliki peluang yang sama untuk menjadi sampel. ${ }^{4}$

Tabel 1. Jumlah sampel masing-masing angkatan

\begin{tabular}{ccc}
\hline Angkatan & Ni & ni \\
\hline 2005 & 54 & 18 \\
2006 & 54 & 18 \\
2007 & 55 & 19 \\
2008 & 32 & 11 \\
\hline Total & $\mathbf{1 9 5}$ & $\mathbf{6 6}$ \\
\hline
\end{tabular}

Pengumpulan data dilakukan pada mahasiswa PSKG FK Unsrat. Izin penelitian diperoleh dari Ketua PSKG FK Unsrat dan Direktur Balai Pengobatan Rumah Sakit Gigi dan Mulut (BP-RSGM) dimana penelitian ini berlangsung. Mahasiswa yang bersedia terlibat dalam penelitian ini diberikan lembar persetujuan untuk mendapatkan persetujuan dalam mengikuti penelitian ini. Setelah mendapatkan persetujuan, responden diberikan kuesioner SAR untuk mencari tahu riwayat lesi yang diduga sebagai SAR dan faktor predisposisi dari lesi yang diduga sebagai SAR yang pernah dialami.

\section{HASIL PENELITIAN}

Jumlah mahasiswa yang terlibat dalam pengisian kuesioner sebanyak 66 orang. Distribusi responden berdasarkan jenis kelamin yaitu, dari 66 responden yang terlibat dalam penelitian ini, terdapat 18 responden (27\%) yang berjenis kelamin laki-laki dan 48 responden $(73 \%)$ yang berjenis kelamin perempuan. Distribusi responden berdasarkan jenis kelamin dapat dilihat pada Tabel 2.

Tabel 2. Distribusi responden berdasarkan jenis kelamin

\begin{tabular}{ccc}
\hline Jenis Kelamin & n & \% \\
\hline Laki-laki & 18 & 27 \\
Perempuan & 48 & 73 \\
\hline Total & $\mathbf{6 6}$ & $\mathbf{1 0 0}$ \\
\hline
\end{tabular}

Usia responden yang terlibat dalam penelitian ini bervariasi antara 22 sampai 26 tahun. Dari 66 resonden yang terlibat dalam penelitian ini, terdapat 7 responden $(10,6 \%)$ yang berusia 22 tahun, 13 responden $(19,7 \%)$ yang berusia 23 tahun, 24 responden $(36,4 \%)$ 
yang berusia 24 tahun, 14 responden $(21,2 \%)$ yang berusia 25 tahun dan 8 responden $(12,1 \%)$ yang berusia 26 tahun. Distribusi responden berdasarkan usia dapat dilihat pada Tabel 3.

Tabel 3. Distribusi responden berdasarkan usia

\begin{tabular}{ccc}
\hline Usia (Tahun) & $\mathbf{n}$ & $\mathbf{\%}$ \\
\hline 22 & 7 & 10,6 \\
23 & 13 & 19,7 \\
24 & 24 & 36,4 \\
25 & 14 & 21,2 \\
26 & 8 & 12,1 \\
\hline Total & $\mathbf{6 6}$ & $\mathbf{1 0 0}$ \\
\hline
\end{tabular}

Dari 66 responden yang terlibat dalam penelitian ini, terdapat 45 responden yang pernah mengalami lesi yang diduga sebagai SAR dan 21 responden tidak pernah mengalami lesi yang diduga sebagai SAR selama masa hidupnya. Persentase dari jumlah responden yang pernah mengalami lesi yang diduga sebagai SAR yaitu sebesar $68,2 \%$ sedangkan persentase dari jumlah responden yang tidak pernah mengalami lesi yang diduga sebagai SAR yaitu sebesar $31,8 \%$. Distribusi lesi yang diduga sebagai SAR pada responden dapat dilihat pada Tabel 4.

Tabel 4. Distribusi lesi yang diduga sebagai SAR pada responden

\begin{tabular}{ccc}
\hline $\begin{array}{c}\text { Lesi yang diduga } \\
\text { sebagai SAR }\end{array}$ & $\mathbf{n}$ & $\mathbf{\%}$ \\
\hline Pernah mengalami & 45 & 68,2 \\
$\begin{array}{c}\text { Tidak Pernah } \\
\text { mengalami }\end{array}$ & 21 & 31,8 \\
\hline Total & $\mathbf{6 6}$ & $\mathbf{1 0 0}$ \\
\hline
\end{tabular}

Responden laki-laki yang pernah mengalami lesi yang diduga sebagai SAR yaitu sebanyak 14 responden $(77,8 \%)$ dari 18 responden yang terlibat dalam penelitian ini. Responden perempuan yang pernah mengalami lesi yang diduga sebagai SAR sebanyak 31 responden $(64,6 \%)$ dari 48 responden yang terlibat dalam penelitian ini. Distribusi lesi yang diduga SAR berdasarkan jenis kelamin dapat dilihat pada Tabel 5.
Tabel 5. Distribusi lesi yang diduga sebagai SAR berdasarkan jenis kelamin

\begin{tabular}{|c|c|c|c|c|c|c|}
\hline \multirow{2}{*}{$\begin{array}{c}\text { Lesi yang } \\
\text { diduga } \\
\text { sebagai } \\
\text { SAR }\end{array}$} & \multicolumn{2}{|c|}{ Laki-laki } & \multicolumn{2}{|c|}{ Perempuan } & \multicolumn{2}{|c|}{ Total } \\
\hline & n & $\%$ & n & $\%$ & $\mathbf{n}$ & $\%$ \\
\hline $\begin{array}{c}\text { Pernah } \\
\text { mengalami }\end{array}$ & 14 & 77,8 & 31 & 64,6 & 45 & 68,2 \\
\hline $\begin{array}{c}\text { Tidak } \\
\text { pernah } \\
\text { mengalami }\end{array}$ & 4 & 22,2 & 17 & 35,4 & 21 & 31,8 \\
\hline Total & 18 & 100 & 48 & 100 & 66 & 100 \\
\hline
\end{tabular}

Usia responden dalam penelitian ini bervariasi, yaitu dari usia 22 tahun sampai 26 tahun. Dari variasi usia tersebut, jumlah responden yang pernah mengalami lesi yang diduga sebagai SAR juga bervariasi. Jumlah responden yang berusia 22 tahun yang pernah mengalami lesi yang diduga sebagai SAR yaitu sebanyak 4 orang $(51,7 \%)$ dari 7 responden berumur 22 tahun yang terlibat dalam penelitian ini. Jumlah responden yang berusia 23 tahun yang pernah mengalami lesi yang diduga sebagai SAR yaitu sebanyak 6 orang $(46,2 \%)$ dari 13 responden berumur 23 tahun yang terlibat dalam penelitian ini. Jumlah responden yang berusia 24 tahun yang pernah mengalami lesi yang diduga sebagai SAR yaitu sebanyak 17 orang $(70,8 \%)$ dari 24 responden berumur 24 tahun yang terlibat dalam penelitian ini. Jumlah responden yang berusia 25 tahun yang pernah mengalami lesi yang diduga sebagai SAR yaitu sebanyak 12 orang $(85,7 \%)$ dari 14 responden berumur 25 tahun yang terlibat dalam penelitian ini. Jumlah responden yang berusia 26 tahun yang pernah mengalami lesi yang diduga sebagai SAR yaitu sebanyak 6 orang (75\%) dari 8 responden yang terlibat dalam penelitian ini. Berdasarkan usia, responden yang paling banyak pernah mengalami lesi yang diduga sebagai SAR dalam penelitian ini yaitu responden dengan usia 25 tahun dan yang paling sedikit yaitu responden yang berusia 23 tahun. Distribusi lesi yang diduga sebagai SAR berdasarkan usia dapat dilihat pada Tabel 6.

Dari 45 responden yang pernah mengalami lesi yang diduga sebagai SAR, didapatkan bahwa sebanyak 41 responden mengaku bahwa lesi yang diduga sebagai SAR yang pernah dialaminya disebabkan oleh 
faktor predisposisi trauma, 9 responden karena faktor predisposisi ketidakseimbangan

hormonal, 11 responden karena faktor predisposisi genetik, 15 responden karena faktor predisposisi stres dan 1 responden karena faktor predisposisi alergi. Dari distribusi responden berdasarkan faktor predisposisi di atas, dapat dilihat bahwa responden mengalami SAR bukan hanya karena 1 faktor predisposisi saja tapi dapat dipicu oleh beberapa faktor predisposisi. Distribusi faktor predisposisi lesi yang diduga sebagai SAR dapat dilihat pada Tabel 7.

Tabel 6. Distribusi lesi yang diduga sebagai SAR berdasarkan usia.

\begin{tabular}{cccccccccccccc}
\hline Lesi yang diduga & \multicolumn{2}{c}{$\mathbf{2 2}$} & $\mathbf{2 3}$ & $\mathbf{2 4}$ & \multicolumn{2}{c}{} & \multicolumn{2}{c}{$\mathbf{2 6}$} & \multicolumn{2}{c}{ Total } \\
\cline { 2 - 14 } sebagai SAR & $\mathbf{n}$ & $\mathbf{\%}$ & $\mathbf{n}$ & $\mathbf{\%}$ & $\mathbf{n}$ & $\mathbf{\%}$ & $\mathbf{n}$ & $\mathbf{\%}$ & $\mathbf{n}$ & $\mathbf{\%}$ & $\mathbf{n}$ & $\boldsymbol{\%}$ \\
\hline Pernah mengalami & 4 & 51,7 & 6 & 46,2 & 17 & 70,8 & 12 & 85,7 & 6 & 75 & 45 & 68,2 \\
Tidak Pernah mengalami & 3 & 42,9 & 7 & 53,8 & 7 & 29,2 & 2 & 14,3 & 2 & 25 & 21 & 31,8 \\
\hline Total & $\mathbf{7}$ & $\mathbf{1 0 0}$ & $\mathbf{1 3}$ & $\mathbf{1 0 0}$ & $\mathbf{2 4}$ & $\mathbf{1 0 0}$ & $\mathbf{1 4}$ & $\mathbf{1 0 0}$ & $\mathbf{8}$ & $\mathbf{1 0 0}$ & $\mathbf{6 6}$ & $\mathbf{1 0 0}$ \\
\hline
\end{tabular}

Tabel 7. Distribusi faktor predisposisi lesi yang diduga sebagai SAR

\begin{tabular}{ccccccc}
\hline \multirow{2}{*}{ Faktor Predisposisi } & \multicolumn{3}{c}{ Lesi yang diduga sebagai SAR } & \multirow{2}{*}{ Total } \\
\cline { 2 - 5 } & \multicolumn{3}{c}{ Pernah mengalami } & Tidak pernah mengalami & \\
\cline { 2 - 6 } & $\mathbf{n}$ & $\mathbf{\%}$ & $\mathbf{n}$ & $\mathbf{\%}$ & $\mathbf{n}$ & $\mathbf{\%}$ \\
\hline Trauma & 41 & 91,1 & 4 & 8,9 & 45 & 100 \\
Ketidakseimbangan Hormonal & 9 & 20 & 36 & 80 & 45 & 100 \\
Genetik & 11 & 24,4 & 34 & 75,6 & 45 & 100 \\
Stres & 15 & 33,3 & 30 & 66,7 & 45 & 100 \\
Alergi & 1 & 2,2 & 44 & 97,8 & 45 & 100 \\
\hline
\end{tabular}

\section{PEMBAHASAN}

Responden yang terlibat dalam penelitian ini berjumlah 66 orang. Sebagian besar responden yang terlibat dalam penelitian ini berjenis kelamin perempuan, yaitu berjumlah 48 responden $(73 \%)$, sedangkan responden yang berjenis kelamin laki-laki berjumlah 18 responden (27\%). Dari 66 responden, terdapat 45 responden $(68,2 \%)$ pernah mengalami lesi yang diduga sebagai SAR dan 21 responden $(31,8 \%)$ tidak pernah mengalami lesi yang diduga sebagai SAR.

Dari penelitian ini didapatkan hasil angka kejadian lesi yang diduga sebagai SAR pada mahasiswa PSKG FK Unsrat sebesar 68,2 \%. Hasil penelitian ini mendukung teori yang mengatakan bahwa angka prevalensi SAR sekitar 5 sampai $66 \%$ dari populasi penduduk dunia dengan rata-rata $20 \% .^{2}$ Kelebihan 2,2\% dari kisaran tertinggi prevalensi populasi penduduk dunia dapat terjadi karena berbagai faktor. Literatur mengatakan bahwa prevalensi SAR tergantung pada daerah yang diteliti. ${ }^{2}$ Hal tersebut menjadi salah satu faktor yang menyebabkan adanya kelebihan persentase pada angka kejadian dari hasil penelitian ini dibandingkan dengan kisaran prevalensi populasi penduduk dunia.

Responden yang pernah mengalami lesi yang diduga sebagai SAR lebih banyak daripada yang tidak pernah mengalami lesi yang diduga sebagai SAR. Hasil penelitian tersebut membuktikan teori yang menyebutkan bahwa SAR merupakan penyakit mulut yang paling banyak dialami oleh populasi manusia dan sering ditemukan oleh klinisi. Sampai saat ini SAR masih merupakan penyakit mulut yang paling sering dialami oleh manusia sepanjang hidupnya. ${ }^{5}$

Jumlah responden laki-laki dan perempuan tidak sama besar, namun berdasarkan penghitungan persentase dari jumlah responden yang pernah mengalami lesi yang diduga sebagai SAR dibandingkan dengan jumlah responden keseluruhan berdasarkan masing-masing jenis kelamin maka didapat angka perbandingannya. 
Sebanyak 48 responden perempuan yang terlibat dalam penelitian in, terdapat 31 orang yang pernah mengalami lesi yang diduga sebagai SAR, sehingga persentase pada responden perempuan dalam penelitian ini sebesar 64,58\%. Pada 18 responden laki-laki yang terlibat dalam penelitian ini, terdapat 14 responden yang pernah mengalami lesi yang diduga sebagai SAR, sehingga persentase pada responden laki-laki dalam penelitian ini sebesar 77,77\%. Dapat dilihat bahwa dalam penelitian ini, angka kejadian lesi yang diduga sebagai SAR lebih tinggi dialami oleh lakilaki daripada perempuan. Dari hasil di atas maka penelitian ini tidak mendukung literatur-literatur dan penelitian dari Jonas dan Mason yang menyatakan bahwa SAR lebih sering dialami oleh perempuan dibandingkan laki-laki ${ }^{6,7,8}$

Tingginya angka kejadian SAR pada perempuan sering dihubungkan dengan faktor predisposisi ketidakseimbangan hormonal yang lebih sering dialami oleh wanita pada siklus menstruasinya. Pada penelitian ini terdapat 9 responden yang mengalami SAR pada siklus menstruasinya. Jumlah tersebut hanya $29 \%$ dari jumlah responden perempuan yang pernah mengalami SAR. Hal inilah yang bisa menyebabkan SAR lebih banyak dialami oleh responden laki-laki dalam penelitian ini. Faktor predisposisi stres yang merupakan faktor predisposisi tertinggi kedua dalam penelitian ini dialami oleh sebagaian besar responden baik laki-laki maupun perempuan sehingga dapat menyebabkan tingginya angka kejadian lesi yang diduga sebagai SAR pada responden laki-laki. ${ }^{9}$

Berdasarkan usia, responden dengan usia 25 tahun paling banyak pernah mengalami lesi yang diduga sebagai SAR, yaitu sebanyak 12 responden $(85,71 \%)$ dari 14 responden yang terlibat dalam penelitian. Responden yang paling sedikit pernah mengalami lesi yang diduga sebagai SAR yaitu responden yang berusia 23 tahun. Dari 13 responden berusia 23 tahun yang terlibat dalam penelitian ini, hanya 6 responden $(46,15 \%)$ yang pernah mengalami lesi yang diduga sebagai SAR. Hasil penelitian ini sesuai dengan literatur yang menyatakan bahwa munculnya ulser SAR akan meningkat seiring dengan pertambahan usia selama dekade ketiga kehidupan (21 sampai 30 tahun). ${ }^{7}$

Penelitian ini menunjukkan bahwa faktor predisposisi dari SAR yang dialami oleh responden bukan hanya satu faktor saja, tapi juga oleh beberapa faktor predisposisi yang memicu terjadinya lesi yang diduga sebagai SAR yang dialami responden selama hidupnya. Dalam penelitian ini, faktor predisposisi trauma merupakan faktor predisposisi yang paling banyak mengakibatkan lesi yang diduga sebagai SAR yang dialami oleh responden. Dari 66 responden, sebanyak 41 responden $(91,1 \%)$ mengaku bahwa lesi yang diduga sebagai SAR yang dialami pada rongga mulutnya muncul setelah mengalami trauma dalam rongga mulut. Trauma yang sering dialami yaitu trauma karena terbentur sikat gigi saat menyikat gigi dan tidak sengaja tergigit bagian tertentu dari mukosa mulut. ${ }^{6}$

Hasil penelitian ini sesuai dengan literatur yang menyatakan bahwa sering dilaporkan munculnya SAR pada daerah yang mengalami trauma karena tergigit dan terbentur sikat gigi. ${ }^{3,6}$ Responden dalam penelitian ini yang menggunakan alat ortodontik (kawat gigi) jarang mengalami lesi yang diduga sebagai SAR namun lebih sering mengalami ulser traumatik, seperti yang dinyatakan dalam literatur bahwa pengguna alat ortodontik (kawat gigi) dapat mengalami ulser traumatik akibat alat yang digunakan. ${ }^{3}$

Tingginya angka kejadian lesi yang diduga sebagai SAR berdasarkan faktor predisposisi trauma disebabkan karena gejalagejala awal akibat trauma dalam rongga mulut seperti tergigit dan terbentur yang seolah-olah menusuk mukosa mulut dan langsung disertai oleh munculnya ulser pada daerah yang tauma. Proses menjadi ulser yang berlangsung cepat dari trauma menjadi lesi yang diduga sebagai SAR yang membuat responden menduga bahwa faktor predisposisi trauma yang mengakibatkan munculnya lesi yang diduga sebagai SAR yang dialaminya. Diasumsikan juga bahwa setiap terjadi trauma maka akan menimbulkan luka. Hal ini memperkuat lagi anggapan bahwa faktor predisposisi trauma yang menyebabkan lesi yang diduga sebagai SAR yang dialami oleh responden. $^{11}$ 
Rongga mulut merupakan cermin yang baik untuk merefleksikan keadaan sistemik seseorang. Keadaan sistemik yang tidak normal dapat tercermin pada rongga mulut dengan manifestasi berbagai lesi yang dapat muncul pada rongga mulut. Kadar hormon di dalam tubuh yang tidak seimbang atau mengalami fluktuasi merupakan salah satu kondisi sistemik yang dapat tercermin dalam rongga mulut. Lesi yang bermanifestasi dalam rongga mulut saat kadar hormon dalam tubuh tidak seimbang yaitu SAR. Hormon-hormon yang tidak seimbang yang dimaksud dalam penelitian ini yaitu hormon estrogen dan progesteron. ${ }^{9}$

Ketidakseimbangan hormonal yang juga diduga menjadi faktor predisposisi lesi yang diduga sebagai SAR dialami oleh 9 responden perempuan. Faktor predisposisi ketidakseimbangan hormonal yang dimaksud dalam penelitian ini yaitu perubahan hormon progesteron dan estrogen saat siklus menstruasi. Itulah alasan mengapa faktor predisposisi ketidakseimbangan hormonal hanya diteliti pada responden perempuan. ${ }^{9}$

Dari 31 responden perempuan yang pernah mengalami lesi yang diduga sebagai SAR, terdapat 9 responden yang mengalami lesi yang diduga sebagai SAR dipicu oleh faktor predisposisi ketidakseimbangan hormonal. Itu berarti sebanyak 29\% responden perempuan yang pernah mengalami lesi yang diduga sebagai SAR, mengalami lesi ini dipicu oleh faktor ketidakseimbangan hormonal pada siklus menstruasinya. Hal ini hampir sama dengan hasil penelitian dari Balan $\mathrm{dkk}$, yang menyebutkan bahwa pada saat siklus menstruasinya, $30 \%$ perempuan mengeluhkan mengalami SAR di rongga mulutnya. ${ }^{9}$

Pada beberapa perempuan, tanda akan datangnya siklus bulanannya dapat diprediksi juga dengan munculnya SAR pada rongga mulutnya. Beberapa perempuan yang mengalami hal tersebut, mukosa mulutnya selalu muncul ulser SAR setiap bulan. ${ }^{9}$ Adanya pengaruh dari hormon progesteron yang memicu SAR ditunjukkan pada penelitian dari Sumintarti dan Erni Marlina yang menyebutkan bahwa pasien SAR memiliki kadar progesteron dibawah normal. Penelitian dari Jones dan Mason telah melaporkan hubungan antara SAR dengan siklus menstruasi. ${ }^{8}$

Sebanyak 11 responden (24\%) mengakui bahwa lesi yang diduga sebagai SAR yang dialaminya juga dialami oleh anggota keluarga (orang tua dan saudara) dan lesi yang diduga sebagai SAR mulai dialami sejak masa kanak-kanak. Ulser SAR yang muncul pertama kali saat kanak-kanak dan adanya riwayat SAR dari orang tua merupakan ciriciri dari SAR yang dipicu oleh faktor predisposisi genetik. Dalam literatur disebutkan bahwa SAR yang dialami oleh orang tua akan diturunkan kepada anaknya. Saudara kandung yang mengalami SAR juga merupakan dampak dari SAR yang dialami oleh orang tua yang diturunkan kepada anaknya. ${ }^{3}$ Adanya hubungan antara riwayat SAR dari orang tua yang memicu SAR yang dialami anak-anaknya telah dibuktikan menggunakan Human Leukocyte Antigen (HLA) namun sampai saat ini hal tersebut baru terbukti pada beberapa grup etnik tertentu. ${ }^{5}$

Faktor predisposisi stres yang memicu lesi yang diduga sebagai SAR dialami oleh 15 responden (33\%) dalam penelitian ini. Beberapa peneliti telah melaporkan hubungan antara SAR dan keadaan stres yang dialami oleh seseorang. Mahasiswa kedokteran gigi merupakan mahasiswa yang memiliki tingkat stres yang tinggi dibandingkan dengan mahasiswa lainnya. ${ }^{10}$ Dalam sebuah studi pada mahasiswa profesi, SAR sering terjadi pada saat ujian dan saat-saat stres lainnya dalam masa perkuliahan. ${ }^{10}$ Pada musim liburan dihubungkan dengan rendahnya frekuensi dari timbulnya SAR. ${ }^{2,11}$

Faktor predisposisi stres merupakan faktor predisposisi tertinggi kedua yang memicu terjadinya lesi yang diduga sebagai SAR yang dialami responden. Hal ini dapat terjadi karena tingginya tingkat stres yang dialami oleh responden yang merupakan mahasiswa program profesi Dokter Gigi dalam aktivitasnya di klinik dan juga aktivitas sehari-hari. Menurut sebuah penelitian dari Polychronopoulou dan Divaris, hal-hal yang dapat menyebabkan stres pada mahasiswa kedokteran gigi yaitu, kurangnya kepercayaan diri untuk menjadi dokter gigi yang baik di masa depan, administrasi fakultas, beban 
kerja, perawatan terhadap pasien, tugas dan ujian. $^{12}$ Stres dapat disebabkan oleh tuntutan tugas dan pemenuhan target pasien untuk menyelesaikan studinya. Ada juga masalahmasalah pribadi di luar kegiatan di kampus yang menyebabkan stres pada responden. Faktor predisposisi stres yang merupakan faktor predisposisi tertinggi kedua yang diduga memicu terjadinya lesi yang diduga sebagai SAR yang dialami responden juga menyebabkan tingginya angka kejadian dari lesi yang diduga sebagai SAR dalam penelitian ini. ${ }^{12}$

Alergi terhadap beberapa makanan seperti kacang, coklat, kentang goreng, keju, susu, terigu, gandum, kopi, sereal, almond, stroberi dan beberapa makanan dari tomat dihubungkan dengan munculnya SAR pada beberapa pasien. Hanya 1 responden $(2 \%)$ pada penelitian ini mengalami lesi yang diduga sebagai SAR saat mengonsumsi ikan. Responden mengalami gatal-gatal pada mukosa mulutnya dan kemudian berkembang menjadi lesi yang diduga sebagai SAR setelah mengonsumsi ikan. Diperkirakan bahwa responden mengalami alergi terhadap ikan yang menyebabkan sensasi rasa gatal pada rongga mulut setelah makan ikan sehingga membuat mukosa mulut responden mengalami luka. Luka ini yang diduga berkembang menjadi lesi yang diduga sebagai SAR pada rongga mulut responden, namun belum ditemukan literatur maupun hasil penelitian yang menyebutkan bahwa ikan dapat memicu lesi SAR yang dialami seseorang. $5,13,14$

\section{SIMPULAN}

Angka kejadiannya lesi yang diduga sebagai SAR pada mahasiswa Program Studi Kedokteran Gigi sebesar 68,2 \%, yang terdistribusi sebagai berikut: Lesi yang diduga sebagai SAR paling banyak terjadi pada responden dengan faktor predisposisi trauma sebesar 91,1\%; faktor predisposisi stres $33,3 \%$; faktor genetik 24,4\%; faktor ketidakseimbangan hormonal $20 \%$; dan faktor alergi sebesar $2,2 \%$.

\section{SARAN}

1. Pentingnya masyarakat untuk bisa mengakses pengetahuan tentang kesehatan termasuk informasi tentang kesehatan gigi dan mulut yang telah dipublikasikan lewat media internet sehingga masyarakat dapat mengetahui faktor predisposisi SAR dan menurunkan angka kejadian SAR dengan cara meminimalisir faktor predisposisinya terlebih dahulu.

2. Diharapkan dapat dilakukan penelitian lebih lanjut dengan cakupan yang lebih luas dan beragam, sehingga hasilnya dapat digunakan secara umum untuk peningkatan derajat kesehatan gigi dan mulut khususnya yang berhubungan dengan penyakit mulut.

\section{DAFTAR PUSTAKA}

1. Scully C. Aphthous ulceration. New Engl J Med. 2006;355:165-72. Available from URL: http://www.nejm.org/doi/pdf/10.1056/NEJMcp 054630

2. Neville BW, Damm DD, Allen CM, Bouquot JE. Allergies and immunologic diseases. In: Oral and maxillofacial pathology $3^{\text {rd }}$ ed. Philadelphia: Elsevier-Saunders. 2009. p. 28590.

3. Field A, Longman L. Oral ulceration. In: Tyldesley's oral medicine $5^{\text {th }}$ ed. Oxford: Oxford University Press. 2003; p. 52-8.

4. Nasir A, Muhith A, Ideputri ME. Buku ajar: metodologi penelitian kesehatan. Yogyakarta; 2011; h. 227-8.

5. Greenberg M, Ulcerative, vesicular, and bullous lesions. In: Greenberg M, Glick M. Burket's oral medicine diagnosis and treatment $10^{\text {th }}$ ed. Ontario: BC Decker Inc. 2003; p. 63-5.

6. Scully C. Aphtous ulcers. Medscape. 2013;1-5. Available from URL: http://emedicine.medscape.com/article/867080 -overview

7. Casiglia JM. Aphtous stomatitis. Medscape. 2013;1-7. Available from URL: http://emedicine.medscape.com/article/107557 0-overview\#a0104

8. Sumintarti, Marlina E. Hubungan antara level estradiol dan progesterone dengan stomatitis aftosa rekuren. Dentofas 2012;11(3):137-41.

9. Balan U, Gonsalves N, Jose M, Girish KL. Symptomatic changes of oral mucosa during normal hormonal turnover in healthy young menstruating women. J Contemp Dent Pract 2012;13(2):178-81. Available from URL: http://www.jaypeejournals.com/eJournals/Sho wText.aspx? ID =2773\&Type=FREE\&TYP=T OP\&IN=_eJournals/images/JPLOGO.gif\&IID $=218 \&$ isPDF $=$ YES 
10. Jain A, Bansal R. Stress among medical and dental students: a global issue. JDMS. 2012; 1(5): 5-7.

11. Cawson RA, Odell EW. Diseases of the oral mucosa: non-infective stomatitis. In: Cawson's essentials of oral pathology and oral medicine. $7^{\text {th }}$ ed. Oxford: Elsevier Science; 2002; p. 192-5.

12. Polychronopoulou A, Divaris K. Perceived sources of stress among greek dental students. Journal of Dental Education. 2005; 69 (6): 687-92.
13. Ghom AG, Mhaske S. Allergic and immunological diseases of oral cavity. In: Textbook of Oral Pathology. India: Jaypee Brothers Publishers; 2008. P. 386-392.

14. Scully C, de Almeida OP, Bagan J, Dioz PD, Taylor AM. Ulcers and erosions: aphtae. In: Oral medicine and pathology at a glance. West Sussex: Wiley-Blackwell. 2010; p. 56-7 